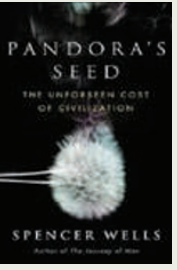

Humans took a wrong evolutionary turn when they invented agriculture, argues geneticist and geographer Spencer Wells in Pandora's Seed (Allen

Lane, 2010). Our hunter-gatherer bodies are ill-equipped for the overly structured life ushered in by managed food production: grain crops have made us sedentary overbreeders, and animal husbandry has entrenched disease. The societal hierarchies that formed to control food resources and maintain inequality have led to the stress-related illnesses of today. Wells suggests that we should instead match our lifestyle to our genetic inheritance.

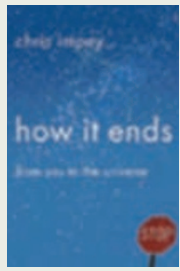

Death writ large is the subject of How it Ends (W. W. Norton, 2010) by astronomer Chris Impey. From individuals to species, our planet and the Universe, the book uses the thread of extinction to poke at issues such as the extension of human life, evolutionary competition and cosmology. Impey cautions that we cannot escape the Sun's eventual dimming and the disintegration of space-time, but takes a holistic rather than a mournful view, seeing existence as a fleeting joy.

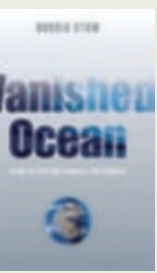

Vanished Ocean (Oxford Univ.

Press, 2010) pieces together the story of Tethys, a vast equatorial waterway that disappeared some 6 million years ago when the continents shifted. Only small pools such as the Caspian Sea remain. Geologist Dorrik Stow explains the detective work that has unearthed Tethys's shadow in rocks from Morocco to China. He relates this ocean's significance for the fossil record, from dinosaurs to the organisms that formed oil, and how its disappearance holds lessons for understanding environmental change today. Stow also recalls the drying up and refilling of the Mediterranean, highlighting the impact of shifting oceans on climate.

\title{
Stem-cell theatrics
}

\section{Staminalia: A Dream and a Trial \\ Written and directed by Valeria Patera Commissioned by the consortia ESTOOLS and NeuroStemcell, among others. 27 May, Gulbenkian Foundation, Lisbon}

Good theatre needs good conflicts - and stem-cell science provides plenty. Written and directed by Valeria Patera, the play Staminalia premiered at the Gulbenkian Foundation in Lisbon on 27 May during the final meeting of the ESTOOLS consortium. Funded by the European Union, the consortium has pioneered tools for human embryonic stem-cell research over the past four years (www.estools.eu).

The production is based on philosopher Armando Massarenti's Italian-language book Staminalia (Guanda, 2008; see Nature 456, 444-445; 2008), which describes the fierce political disputes that have erupted over stemcell research in Italy. The play was also inspired by Elena Cattaneo, a leading stem-cell scientist at the University of Milan who is a prominent voice in the Italian public debate.

The play is in two parts: a trial and a dream. The trial unfolds as a dialogue between a stemcell scientist and her religious fundamentalist daughter. The walls of the scientist's university have been tarnished with graffiti equating stem-cell labs with Auschwitz, and the harsh confrontation between mother and daughter exposes two incompatible views of the world and of our place within it.

The dream is the most convincing section of the play; drama thrives when clashes are whispered rather than shouted, when tension is evoked rather than declared. A tense piece of modern ballet conveys the unease unleashed in the sleeping mother by her daughter's accusations. Two dancers - playing supportive angels and doubt-mongering demons - sculpt the space, while images of stem cells and Catholic clerics flash onto the screen behind them.

The contrast between the near-naked dancers and the shrouded cardinals with faces distorted as if in a Francis Bacon painting powerfully conveys the clash between two views of the flesh - joyful and liberated versus sinful and oppressed. A further contrast is in scale, between the macroscopic bodies on stage and their molecular equivalents on the screen, the latter a dance of cells lit up with the markers that have become the epistemic and aesthetic canon of stem-cell science.

These juxtapositions highlight how, in modern biology - from genome sequencing to synthetic biology - we understand life through the same tools that allow us to redesign it. Science has developed beyond mere observation, beyond the paltry task of discerning "the seed from the oak tree", as the mother describes it in the trial. The dream reminds us that we understand bodies by breaking them apart into components and that this microscopic gaze brings with it the power of molecular intervention. The more we learn about cells, the more we are able to manipulate them - and the more options society has to use them.

Which options should we choose? In the age of simple observation, nature was considered a source of moral norms. With the advent of molecular intervention, nature has become a source of tools with which to transgress its own limits. Staminalia captures this tension

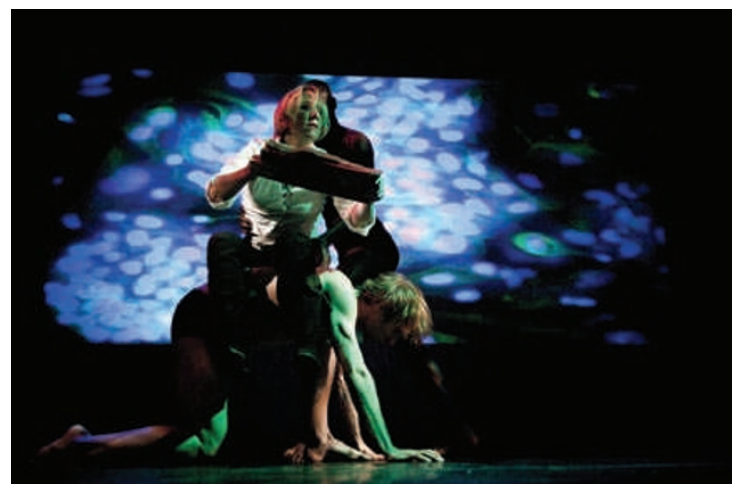

Dance, drama, ethics - and biotechnology.

well. The dancers' bodies are natural both in their near-nakedness and in the perfection of their movements, achieved through years of training. The play prompts us to ask whether our response to them would be different if artificial enhancement of our bodies could replace countless hours in the gym. In the age of synthetic genomes and cell-fate reassignment, will we be able to tell natural from unnatural? And does that matter?

We will need the best of our collective creativity to align the scientific and social innovations of the molecular age. Staminalia is thus a fitting celebration of ESTOOLS, a consortium that has put bioethical analysis and creative public engagement at the forefront of its activities. Giuseppe Testa is a stem-cell biologist and bioethicist at the European Institute of Oncology, Milan, Italy. His forthcoming book with Helga Nowotny is Naked Genes: Reinventing the Human in the Molecular Age.

e-mail: giuseppe.testa@ifom-ieo-campus.it

Further performances of Staminalia are planned in Germany, Italy, Norway, Spain, Sweden and Britain. 